\title{
FEMINIST MOVEMENTS IN CENTRAL AND EASTERN EUROPE
}

\author{
JULIA KUBISA, KATARZYNA WOJNICKA
}

In recent years, Central Eastern Europe has been witnessing an unprecedented wave of feminist protests. In spring 2016, a group of Ukrainian, Russian and later, Kazakh activists organised a social media based campaign, where they stressed the immutable prevalence of sexual and gender-based violence in contemporary post-Soviet societies. Campaigners used the \#ЯнеБоюсьСказать (\#IamNotScaredToSpeak) hashtag, which was quickly shared by thousands of women in the above-mentioned countries. The action clearly demonstrates similarities to the North-American and later, global \#metoo movement. It is important to note however, that the Eastern European campaign not only preceded the more famous NorthAmerican mobilisation, but was also organised by, so called, "ordinary women" unlike its celebrity-focussed counterpart. In the paper entitled "The \#яНеБоюсьСказать (\#IamNotScaredToSpeak) campaign in the Russian speaking community of Facebook in July 2016: A Critical Discourse Analysis" Anna Sedysheva provides a unique analysis of the character of mobilisation that had started in Ukraine and was overtaken by Russian activists. Attacks on reproductive rights have galvanised public opinion and brought thousands of people into the streets in Poland. An effective platform, countering right-wing and highly patriarchal governments, has started to form around these protests.

Recent women's mobilisations are not restricted exclusively to this region, as feminist protests have occurred in other parts of the world as well. Over the past several months, we have witnessed the emergence of the global \#metoo movement, women's marches in the USA, 
and the anti-violence Latin American protest actions organised by NiUnaMenos, to name but a few. However, the specificity of Central Eastern European mobilisations requires a closer look, as they are strongly connected to the recent political changes that have occurred in several countries in the region.

One of the largest mobilisations in recent times, the Polish Black Protest and the AllPoland Women's Strike, can be viewed as part of women's protests taking place around the world. Women in Poland organised several influential demonstrations against the total ban on abortion that was planned by the government in 2016. It was called "Black Protest" due to the colours of the clothes worn by the participants. It was popularised by a \#czarnyprotest (blackprotest) hashtag. The peak of the protests organised on 3rd October 2016, called AllPoland Women's Strike, mobilised thousands of women all over the country, becoming the first wide-spread demonstration on such a scale since the early 1980s and the first Solidarność social movement. It became an important point of reference for international women's movements and one year later, women in Poland joined the International Women's Strike on 8 March 2017 (see Majewska 2018, Korolczuk et al 2019).

These events, unprecedented in terms of scale, led us to enquire whether we are dealing with some kind of Central Eastern European specific movement or if there is a more global aspect to the changing phenomenon of women's mobilisation. While we cannot answer this question directly, the articles collected in this special issue show a variety of actions in Poland, Romania, Russia, Ukraine and internationally. These actions are taken up by women against problems that have much in common, such as sexual violence, severe limitations of reproductive rights and the rise of the political right-wing. The precarious status of women's rights in the region are revealed by authors analysing different aspects of Black Protest, namely Anna Sedysheva on the \#Iamnotafraidtospeak movement in Russia and Ukraine, and Alexandra Ana on the precarious locations of Romanian feminist activists. These are rights and issues that can be easily dismissed, both in discursive terms and in terms of political decisions. Yet, their social and political dynamics, as well as their theoretical implications, have been inadequately analysed and the most pivotal problems they raise are still unresolved, despite having been prominent in the feminist agenda for decades.

The impact and strength of this new type of mobilisation, which can be seen as the most recent face of new social movements (Melucci 1980), definitely says something new about the current need for feminism. The political opportunity structure (Della Porta and Diani 2009) has recently been widened, unlike in previous research on feminist mobilisations in the region, which was focussed mainly on middle-class, white, native inhabitants from big cities. This is posited in the papers "Rocking the small-town boat: Black Protest activists in small and provincial Polish cities" by Magdalena Muszel and Grzegorz Piotrowski, "Solidarity despite and because of diversity, Activists of the Polish Women's Strike" by Jennifer Ramme and 
Claudia Snochowska-Gonzalez or, in the case of migrant women's transnational mobilisation, see Greta Gober and Justyna Struzik's paper entitled "Feminist transnational diaspora in the making. The case of the \#BlackProtest". The new political opportunity structure is not limited solely to a more diverse geographical dimension. It also includes new forms of on-line activism (Sedysheva 2018), new facets of protest forms (Kubisa and Rakowska 2018) and new protest's rhetoric (Kubisa and Rakowska 2018).

The layers and levels of discrimination, i.e. institutionalised misogyny in the form of attempts to restrict women's reproductive rights and the great scope of sexual harassment in every sphere of social life, is revealed by \#metoo action. This is understood to be a new form of social mobilisation, pushing for the urgent need for action. Indeed, recent mobilisations have brought new types of actions with them. We claim that the particular novelty of recent mobilisations concerns the action, which has taken place in new contexts, in political, economic and cultural terms, in the post financial crisis social landscape, marked by austerity measures. The new populist governments, which combine a pronatalist approach and the objectification of women with a certain investment in social welfare, serve as a different kind of opposition to what was in place before. That is to say neoliberal governments, which avoided all debate on reproductive rights and refused to make social expenditure a priority. And yet, the feminist movement encounters threats of de-politicisation and ngoization, as Alexandra Ana discusses in her article.

The unprecedented wave of women's protests raises new questions for feminism, both for its theoretical investigations and for political practice. The Black Protest in Poland on 3 October 2016 took the form of a strike. A strike is a refusal of work, but what kind of work was being refused in this case? Julia Kubisa and Katarzyna Rakowska analyse the consequences of the use of industrial relations terminology for reproductive rights protests, both for women's movements and for trade unions, with the latter being the only organisations formally entitled to organise a strike.

It pays to reflect on how new forms of women's protests shape feminist debates. As the presented analysis suggests, in the Central European context one can observe a shift towards a more intersectional feminism (Collins \& Bilge 2016), in which issues of gender, class, citizenship and status are brought together. In the context of social movement scholarship, intersectionality can be defined as an approach (both in terms of theory and practice) which enables analysis of such phenomena that is focussed on the overlap of a variety of social categories. Taking these together influences the social position of both individuals and groups in society, as well as the dynamic of particular social movements themselves (Wojnicka 2019). Such an approach enables a view of women's activism, not as homogeneous collective entities, but rather a colourful mosaic of unique but intertwined phenomena. We therefore place strong 
significance on the usage of the plural form "feminisms" rather the singular, and therefore, limiting "feminism".

Moreover, inverting the framework of Joan Acker's "Class questions - Feminist Answers" (2005), together with the authors of the special issue articles, we stress the importance of including class and, in general, a more intersectional approach in contemporary Central and Eastern European women's protests analysis. Against the backdrop of these events we want to ask what the role of current women's movements could be in disentangling the unconscious alliance between feminism and neoliberalism? Do these movements provide space for care and mutual support in a way that allows us to move beyond this toxic relationship? The postulates formulated by current women's movements, especially in the Central and Eastern European context, concern the reproductive rights and dignity of women. What do these postulates express? The universalism of woman's experience? A sort of "middle class takeover" that universalises its experience to all participants? And whose voice is heard in them and why? Whose is not, and, again, why? Was the question of "representation of interests of the ordinary woman" that has been a recurring argument against feminism finally solved?

Finally, the new type of activism, as observed in Poland and other countries in the region, raises questions about the type of mobilisation. In several papers the participants of mobilisations such as the Black Protest and the Women's Strike were defined as independent initiatives of "ordinary" women who had hitherto remained silent. Such arguments seem to be prevalent in the analysis of both Black Protest (Muszel and Piotrowski 2018; Ramme and Snochowska - Gonzalez 2018, and, to some extent, Nawojski, Pluta and Zielińska 2018) and on-line anti-violence activism (Sedysheva 2018). One conclusion that arises from discussions provided in the papers seems to suggest that in recent mobilisation, "ordinary" women, despite their constant presence in the feminist movement (Wojnicka 2019) finally gained public attention, which in the past was focussed mainly on "celebrity" feminists. Moreover, they gained voice due to the new multiway means of communication and the multitude of protest locations (Kubisa 2016, Kubisa 2018, Majewska 2017). The model of organisation of the protests analysed in this Issue allows a multiplicity of voices and narrations, in which the senders and the receivers constantly construct and re-construct the messages, amplifying the collective voice. It makes a significant change compared to older forms of feminist activities, organised in bigger cities, directed by the few. However, one can consider whether without this previous feminist activity, the current manifestation would be even possible (Kubisa 2017).

The current women's movement faces unprecedented challenges in political terms. The same Polish government that refuses fundamental women's rights, however, has adopted select social policies that help to secure the material existence of numerous families in Poland and effectively diminish labour market precarity. How can the women's movements solve this puzzle? As an answer, the authors emphasise the diversity of participants and the grass-roots 
character of protests. This enables them to show that "prosocial" governments can be "antisocial" at the same time. Even though the governmental policies financially support selected families, their political approach is still based on objectification of women. Women's movements, on the contrary, are giving space and voice to these issues, which is transforming into women's agency (Kubisa 2017).

Thus, the main scope of this Special Issue is to shed the light on the specificity of recent feminist mobilisations in Central Eastern European countries, framed as a new form of women's social movement. The articles provide a contribution to the challenge of mapping the variety of movements in CEE countries. We present the analysis of certain types of protest and movements, as seen from local, national and transnational perspectives. Moreover, we deliver analyses of the interconnections between new forms of women's protest and neoliberalism. These are interconnections that can serve as a form of legitimisation of neoliberalism as well as attempts to rally against its ideology. The aim of this Special Issue is therefore, to examine the variety of forms of contemporary mobilisations, in all their social, political and theoretical implications. Hence, we especially focus on addressing the following points:

- The strategies of social movements - The organisational model of these protests and what is novel about them in terms of strategies of mobilisation, patterns of leadership, alliances and narration, and institutionalisation (Ana 2018)

- The place of social class in the movement, in its narration and in its strategies (Muszel and Piotrowski 2018; Ramme and Snochowska-Gonzalez 2018)

- The strike as a form of women's social protest (Kubisa and Rakowska 2018)

- The new actors and patterns of mobilisation such as social media (Sedysheva 2018)

- The human geography of women's protests - on the local, national, transnational and virtual levels - The forms of international solidarity, transnational activism and their local varieties (all authors)

- The political framework of the protest (Nawojski, Pluta and Zielinska 2018; Muszel and Piotrowski 2018)

We hope that the Special Issue will ignite a broader debate in feminist analysis, on the political and theoretical relations between the presented women's movements and the direction of contemporary feminisms. This Special Issue is a contribution to further theoretical and methodological investigations of the variety of women's protests.

We find the issue of representation of "ordinary women" especially vital in regard to the political context. Populist governments are eager to claim that they are representing "ordinary people", while advancing anti-women policies. Feminist movements in CEE countries clearly need comprehensive, intersectional frameworks for inclusive political actions that would 
recognise the specifics of CEE contexts - the state and the gender regimes, and the recognition of gender relations. Specifically, we find it important that feminist movements should be theorised from within.

Finally, along with the above-mentioned topics that require further reflection and development, one particular issue connected to contemporary women's activism seems to be missing and its absence is significant. This particular issue concerns men and masculinities and their standpoint regarding the most current feminist mobilisation. This is especially important given that a large number of Central Eastern European countries are experiencing a certain form of re-masculinisation and a triumphant revision of patriarchy (Pascall \& Lewis 2004; Novikova 2008; Tereskinas 2012), all of which raises questions about current sources of power and domination. To grasp these questions, we must engage in a deeper analysis of the current interlinking between masculinities, state and capital that creates the model of hegemonic masculinity (Connell 1995). Men and masculinities cannot be seen as a singular phenomenon and the question of different types of masculinities (subordinated/marginalised/nonhegemonic) and the variety of men's standpoints and reactions towards women's mobilisations therefore needs deeper reflection. Since protests are organised in opposition to the state, which is supported by a variety of (anti-choice, anti-feminist) organisations, the analysis of the dynamic of counter-movements requires similar attention. Despite these needs, however, the analysis of men's engagement has not been analysed, neither in the most current feminist initiatives nor in counter-movements, which has created a significant gap in knowledge regarding contemporary social mobilisation in Central and Eastern Europe. This particular absence is even more surprising taking into account the fact that critical men and masculinities studies in the region have significantly developed in the last decade (Wojnicka and Ciaputa 2011, Wojnicka and Kluczyńska 2015; Hrzenjak 2017). Moreover, the analysis of (also Eastern) European and Polish male anti- and pro-gender activism, that had been conducted before 2016 shows, that there is a growing number of men who identify themselves as feminists (Wojnicka 2012, Wojnicka 2016, Wojnicka 2017; Bergmann, Wojnicka and Scambor 2014).

This raises several questions regarding the contemporary position of "male allies" in the region: Have male feminists suddenly disappeared or decided to step back from sight and give more space to women? Or perhaps, the current mobilisation that included the \#metoo movement has revealed a number of weaknesses of the "male allies" movement who not only did not hold the candle and were unable to go beyond declarative support for women's rights, but also, in several cases showed that they were "made from paper" male feminists and guardians of the most fundamentalist facet of patriarchy (Czyż at al. 2017). These questions require urgent answers. 


\section{References}

Acker, Joan. 2005. Class Questions, Feminist Answers. AltaMira Press.

Bergmann, Nadja, Wojnicka, Katarzyna and Elli Scambor. 2014. Framing the Involvement of Men in Gender Equality in Europe: Between Institutionalised and Non-

Institutionalised Politics. MCS - Masculinities and Social Change Vol. 3 No. 1: 62-82 doi: http://dx.doi.org/10.4471/mcs.2014.42

Connell, Raewyn. 1995. Masculinities. St. Leonards, New South Wales: Allen \& Unwin.

Czyż, Sara, Dymińska, Dominika, Wieczorkiewicz, Patrycja, Ziółkowska, Agnieszka and four annonimuos authors. 2017. „Papierowi feminiści. O hipokryzji na lewicy in nowych twarzach polskiego metoo." Codziennik Feministyczny.

http://codziennikfeministyczny.pl/papierowi-feminisci-nowe-twarze-polskiego-metoo/ Della Porta, Donatella, and Mario Diani. 2009. Social Movements. Newark: Wiley.

Fraser, Nancy. 2009. Feminism, capitalism and the cunning of history. New Left Review. 56. Mar/Apr 2009.

Hill Collins, Patricia, and Sirma Bilge. 2016. Intersectionality. Cambridge: Polity Press.

Hrzenjak, Majda. 2017. Kritične študije moških in moškosti: konteksti, koncepti in aplikacije. Casopis za kritiko znanosti, domišlijo in novo antropologijo 267: 9-23.

Korolczuk, Elżbieta, Kowalska, Beata, Ramme, Jennifer and Snochowska-Gonzalez, Claudia. 2019. Bunt kobiet. Czarne Protesty i Strajki Kobiet. Europejskie Centrum Solidarności.

Kubisa, Julia. 2018. March. Ufajmy kobietom. Krytyka Polityczna. https://krytykapolityczna.pl/kraj/julia-kubisa-czarny-piatek-ufajmy-kobietom/

Kubisa, Julia. 2017. Zwykły feminizm. Ruch feministyczny w Polsce a kwestia socjalna. red. Dorota Szelewa. Fundacja ICCRA, Fundacja F. Eberta

Kubisa, Julia. 2016. October 10. Odzyskajmy Polskę dla kobiet. Krytyka Politycz̨na. Retrieved from http://krytykapolityczna.pl/kraj/odzyskajmy-polske-dla-kobiet/

Pascall, Gillian, and Jane Lewis. 2004. Emerging Gender Regimes And Policies For Gender Equality In A Wider Europe. Journal Of Social Policy 33 (3): 373-394. doi:10.1017/s00472794A0400772x.

Majewska Ewa. 2017. Tramwaj zwany uznaniem. Feminizm i solidarnośćpo neoliberalizmie. Warszawa: Instytut Wydawniczy Książka i Prasa

Majewska Ewa. 2018. Kontrpublicz̨ności ludowe i feministycz̧ne. Wrçesna „Solidarnośc” i czarne protesty. Warszawa: Instytut Wydawniczy Książka i Prasa.

Melucci, A. 1980. The New Social Movements: A Theoretical Approach. Social Science Information 19 (2): 199-226. doi:10.1177/053901848001900201.

Novikova, Irina. 2008. Gender Matters In The Baltics. Ríga: Latvijas Universitate Akadēmiskais apgāds.

Tereskinas, Arturas. 2012. „Post-Soviet masculinities, shame, and the archives of social suffering in contemporary Lithuania“. In Women and Gender in Postwar Europe From Cold War to European Union. Ed. J. Regulska and B. S. Smith. New York: Routledge. 
Wojnicka, Katarzyna. 2019. "Social movements and intersectionality: the case of migrants' social activism". In: Social stratification and social movements. Digging in a complex relationship. Ed. S. Zajak and S. Haunss. London: Routledge

Wojnicka, Katarzyna. 2017. Men's pro-gender equality initiatives in Europe. Ćasopis za kritiko znanosti, domisljijo in novo antropologijo 267: 189-202.

Wojnicka, Katarzyna. 2016 Masculist groups in Poland. Aides of mainstream antifeminism. International Journal for Crime, Justice and Social Democracy 5/2 doi:10.5204/ijcjsd.v5i2.306.

Wojnicka, Katarzyna. 2012.The profeminist movement in Poland. GENDER Zeitschrift für Geschlecht, Kultur und Gesellschaft 3/2012: 25-40.

Wojnicka, Katarzyna, and Urszula Kluczyńska. 2015. "Men And Masculinities Research In The European Dimension Guest Editors' Introduction". Studia Humanistyczne AGH 14 (2): 7. doi:10.7494/human.2015.14.2.7.

Wojnicka, Katarzyna and Ewelina Ciaputa. 2011. „Wprowadzenie: refleksja naukowa nad społeczno-kulturowymi fenomenami męskości” In Karuzela z mę̧çyznami. Problematyka meskości w polskich badaniach społecznych. Ed. K.Wojnicka and E. Ciaputa. Kraków: Oficyna Wydawnicza Impuls.

Wojnicka, Katarzyna. 2009. „Polskie sqare feministki - portret socjologiczny” In: Kobieta w kulturze i społeczeństwie. Ed. B.Kowalska, K.Zielińska and B. Koschalka. Kraków: Rabid.

CITATION: Kubisa, Julia and Katarzyna Wojnicka. 2018. "Feminist Movements in Central and Eastern Europe" Praktyka Teoretyczna 4(30): 7-14.

DOI: $10.14746 /$ prt.2018.4.0 